\title{
O misaonim procesima osoba s poremećajem iz autističkog spektra iz perspektive filmskog medija: slučaj Temple Grandin
}

\author{
Marina Biti*
}

Eva Brlek**

\section{SAŽETAK}

Neurokognitivna perspektiva primjenjuje se kao ishodište za prepoznavanje objektivnih uzroka poremećaja iz autističkog spektra, kao i komunikacijskih teškoća koje proizlaze iz samog poremećaja. To se ishodište nadograđuje kroz studiju slučaja praćenu posredstvom filmskog djela Temple Grandin redatelja Micka Jacksona. Upozorava se na sposobnost filmskog medija i kreativnih praksi da komunikacijske teškoće osoba s poremećajem iz autističkog spektra približe svijesti većine te da doprinese kvalitetnijem tretiranju pacijenata, kao i prevladavanju društvenih predrasuda, unapređivanju kvalitete komunikacije te višem stupnju integracije osoba s poremećajem iz autističkog spektra u sferu socijalne stvarnosti.

Ključne riječi: poremećaj iz autističkog spektra, teorija uma, drugost, mimesis, kinesis

Ja nisam kao drugi ljudi. Ja razmišljam u slikama i povezujem ih.

Temple Grandin

\section{Uvod}

Kognitivni se procesi velikim dijelom očituju u sposobnostima primanja i obrade informacija dobivenih iz okoline, odnosno detektiranja ponašanja i mentalnih stanja

\footnotetext{
* Marina Biti, redoviti profesor, Filozofski fakultet Sveučilišta u Rijeci, e-mail: marina.biti@gmail.com

** Eva Brlek, doktorandica, Sveučilište Sjever, e-mail: evbrlek@unin.hr
} 
drugih ljudi te procesuiranja informacija sa svrhom prilagođavanja vlastitih reakcija poticajima zaprimljenim unutar komunikacijskog čina. Oslonac za procesuiranje informacija čini iskustveni okvir koji omogućuje da neposredni komunikacijski poticaj sučelimo danom iskustvenom modelu, odnosno da oblikujemo reakcije primjerene socijalnim standardima komuniciranja. Kod osoba s poremećajem iz autističkog spektra razabire se, međutim, postojanje deficita izvršnih funkcija, i to upravo onih koje se odnose na kognitivni mehanizam koji pokreće mapu standardiziranih predložaka, aktivirajući s njome i teoriju uma iz koje se izvodi procjena i omogućuje oblikovanje i izvršavanje primjerene reakcije. Riječ je o manjku koji rezultira neprilagođenošću reakcije uobičajenim komunikacijskim standardima, što rezultira nerazumijevanjem, ako ne i stigmom kojom okolina, nažalost prečesto, penalizira različitosti u društvenom prostoru.

U ovom radu osnovne značajke kognitivnog funkcioniranja osoba s poremećajem iz autističkog spektra, uz poseban naglasak na vizualno razmišljanje, prezentirat će se na slučaju Temple Grandin, osobe s dijagnosticiranim stanjem autizma. Slučaj ove američke znanstvenice koja je svoju karijeru u području znanosti o životinjama izgradila usprkos spomenutom deficitu, a ponajviše zahvaljujući svojim sposobnostima razmišljanja u slikama, ekstenzivno je dokumentiran, dijelom njezinim vlastitim svjedočanstvima i promišljanjima o autizmu (Thinking in Pictures, 1995; The Autistic Brain: Thinking Across the Spectrum, 2013), kao i zahvaljujući interesu znanosti za njezin slučaj o kojemu svjedoči knjiga britanskog neurologa i povjesničara znanosti Olivera Sacksa, An Anthropologist on Mars (1995).

Uzimajući u obzir izvore, mi ćemo se usredotočiti na izvor drukčije vrste: na biografski film u režiji Micka Jacksona koji nosi naziv Temple Grandin (2010), gdje lik Temple interpretira za tu ulogu nagrađena glumica Claire Danes (nagrade Golden Globe i Screen Actors Prizes). Nije naodmet istaknuti da je produkciju filma podržala i sama Temple Grandin te da je djelo nagrađeno s pet Primetime Emmy nagrada te s dvije nagrade i više nominacija za Creative Arts Emmy Awards. O autentičnosti je toga prikaza posvjedočila i prava Temple Grandin, koja je interpretaciju Claire Danes ocijenila rečenicom „Ona je postala ja”, a sam film kao djelo koje joj je omogućilo povratak u vrijeme njezina djetinjstva i mladosti. ${ }^{1}$

Neurokognitivna perspektiva nužno je ishodište pri dekonstruiranju objektivnih uzroka koji osobe s autizmom opterećuju komunikacijskim specifičnostima i činitelj su njihova otežana funkcioniranja u uvjetima razmjene koje na takve teškoće uglavnom diktira neosjetljiva većina. To ćemo ishodište nadograditi uvidima bazi-

\footnotetext{
${ }^{1}$ Parafraza se oslanja na odlomak iz teksta Ricka Lymana [Lyman, R. (2010) “ No More Crushes; This Is Serious ”, The New York Times. https://www.nytimes.com/2010/01/31/ arts/television/31 danes.html?pagewanted $=1]$.
} 
O misaonim procesima osoba s poremećajem iz autističkog spektra...

ranim na filmskim uprizorenjima inače nevidljivih misaonih procesa, aktualizirajući pritom sposobnost filmskog medija i kreativnih praksi da komunikacijske teškoće osoba s poremećajem iz autističkog spektra približe svijesti većine te da time doprinesu prevladavanju predrasuda, unapređivanju kvalitete komunikacije i socijalnoj integraciji osoba s autizmom.

\section{Neurokognitivna polazišta}

Kognitivni se procesi tiču sposobnosti obrade podataka koji do nas pristižu zahvaljujući djelovanju perceptivnih mehanizama, odnosno obradi podražaja koje zaprimamo putem različitih osjetila, a s druge se strane tiču neposredno i posredno stečenih znanja. Ti su procesi uvjetovani mnogim objektivnim faktorima, no označeni su i brojnim subjektivnim karakteristikama koje sudjeluju u procesu integriranja informacija zbog čega rezultiraju raznolikim, no u pravilu međusobno usporedivim poimanjima i tumačenjem svijeta. Deficiti u kognitivnim procesima kod funkcioniranja osoba s poremećajem iz autističkog spektra narušavaju upravo taj moment usporedivosti budući da se tiču izvršnih funkcija putem kojih se oblikuje sposobnost shvaćanja kognitivnog funkcioniranja drugih ljudi i njihovih - često drukčijih od naših, ali ipak sumjerljivih našima - uvjerenja, težnji, preferencija, namjera, vrijednosti. Kao pojedinci, svi mi u pravilu raspolažemo instrumentima procjene iz kojih gradimo vlastitu teoriju uma, odnosno sposobnost koja omogućuje prepoznavanje i anticipiranje reakcija drugih ljudi, čak i onda kada su njihove reakcije i stavovi bitno različiti od naših vlastitih. Iako se pritom ne radi, kako se prvotno mislilo, o jedinstvenoj, središnjoj izvršnoj funkciji, već prije o nizu različitih a međusobno povezanih procesa potrebnih za svrhovito, ciljno usmjereno ponašanje (Anderson, 2002: 71-82), uklapanje pojedinca u socijalnu sferu i snalaženje u interakcijskim situacijama uvjetovano je sinergijskim djelovanjem svih tih procesa, barem do razine onog minimuma koji se percipira kao preduvjet socijalne prilagođenosti ljudskih jedinki. Svakodnevni društveni život facilitiran je sposobnošću procjene ponašanja drugih ljudi, kao i prepoznavanjem njihovih ciljeva, emocija i uvjerenja, što je omogućeno upravo sinergijskim djelovanjem više kognitivnih sustava koji prerastaju u cjelovitu teoriju uma (Tager-Flusberg, 2007: 311-315).

Procesi u podlozi izvršnih funkcija su sljedeći: planiranje, vremenska organizacija ponašanja, anticipacija cilja, započinjanje aktivnosti, nadgledanje aktivnosti, sposobnost inhibiranja ili odgađanja odgovora, evaluacija odgovora, kognitivna fleksibilnost (Anderson, 2002; Damasio i Anderson, 1993; Luria, 1969; Welsh, Pennington i Groisser, 1991; Zelazo, Carter, Reznick i Frye, 1997 prema Šimleša, 2011: 91-114). Djeca s autizmom općenito imaju ograničenja izvršne funkcije koja zahvaćaju sfere planiranja te fleksibilnosti ili radne memorije u kombinaciji s inhibitor- 
nom kontrolom. Izvršavanje zadataka lažnog vjerovanja od strane djeteta značajno je povezano aspektima izvršne kontrole (Tager-Flusberg, 2007: 311-315). Kritični se period u razvoju teorije uma odvija u predškolskom periodu, između treće i pete godine života, (Wellman, Cross i Watson, 2001: 655-684), iako se proces začinje ranije i traje cijeli život. Baron-Cohen u teoriji uma stavlja naglasak na kognitivnu dimenziju socijalnih i komunikacijskih praksi, odnosno poteškoća u provođenju tih praksi kada je riječ o osobama s poremećajem iz autističkog spektra. To nam skreće pažnju na one procese koji oblikuju sposobnost razumijevanja vlastitih i tuđih mentalnih stanja, kao i na povezanost između samih stanja i djelovanja. Teorija uma u naravi je kognitivno uspostavljena mapa socijalnih odnosa i shematiziranih predodžbi, s varijablama koje individuama pomaže u snalaženju u raznolikim socijalnim situacijama. Manjak u toj sferi pokazuje se tipičnim upravo za osobe s poremećajem iz autističkog spektra te ga je tako moguće zapaziti i kod Temple Grandin, koja nerijetko ističe, a još češće pokazuje, da se ne snalazi u kontaktu s ljudima, da ih ne razumije te da ne prepoznaje njihova emocionalna stanja.

Sukladno navedenom, dijagnostički se kriterij vezan uz poremećaj iz autističkog spektra tiče uočljivih odstupanja na području socijalne interakcije i komunikacije, podbacivanja u sferi socio-emocionalne recipročnosti, u neverbalnoj komunikaciji i ponašanju, kao i u razvoju, održavanju i razumijevanju međuljudskih odnosa. Postoje i bihevioralni pokazatelji autizma kao što su repetitivni ili stereotipni oblici ponašanja, rutine i ritualno ponašanje, uski i specifični interesi s intenzivnim fokusom pažnje te hipoosjetljivost ili hiperosjetljivost na senzorne podražaje (Američka pedijatrijska udruga, 2014). Čak i verbalne osobe s autizmom imaju komunikacijskih poteškoća i suočavaju se s brojnim izazovima u svakodnevnom životu. Sklone su repetitivnom ponavljanju dijelova dijaloga, ponekad preuzetih iz komunikacije iz direktnog okruženja, ponekad iz posrednih izvora (primjerice, s televizije). Najčešće komunikacijske poteškoće tiču se (ne)razumijevanja idioma, metafora, sarkazma, humora. U pravilu, to su osobe koje uspijevaju svladati određen korpus fraza koje prije svega služe samom potvrđivanju komunikacijskog kontakta (,Zovem se...”; „Kako si...”; „Kakvo je vrijeme...”), no koje se teško ili nimalo ne snalaze s odgovorima ako oni odstupaju od fatičke funkcije. Njihove se poteškoće očituju kroz nerazumijevanje perspektiva drugih osoba od kojih se distanciraju izbjegavajući kontakt očima, dok im pogled nerijetko reagira na senzorne podražaje različitih vrsta. Ako im se pruži prilika da govore o temi koja je njima važna, takve će se osobe upustiti u monologe s mnoštvom detalja i opisa koji će se slušateljima činiti irelevantnima. Njihova je participacija u recipročnoj komunikaciji rijetka. Govor im je glasan, tijek izlaganja neprilagođen izmjenama fokusa, a rečenice koje izgovaraju mogu biti u izrazitu neskladu sa socijalnom situacijom. Razumijevanje emocionalnih stanja drugih ljudi najčešće izostaje. S obzirom na to da klinička slika 
O misaonim procesima osoba s poremećajem iz autističkog spektra...

poremećaja iz autističkog spektra varira u stupnju i zastupljenosti pojedinih simptoma, smatra se opravdanim govoriti o spektru razvojnih poremećaja.

Valja napomenuti i to da je poremećaj iz autističkog spektra neurorazvojni poremećaj multikauzalne etiologije zbog čega se uz genetske faktore ispituju i okolinski faktori. U jednom od najcitiranijih radova 20. stoljeća, naslovljenom Autistic Disturbances of Affective Contact (1943: 217-250), američki je psihijatar Leo Kanner opisao slučajeve jedanaestoro djece, a kroz koje i fenomen „infantilnog autizma”. Sva su djeca imala ograničene interese i oštećenu socijalnu interakciju od ranog djetinjstva te teška govorna ograničenja koja su pratila i izrazitu rigidnost u ponašanju. Sam termin autizam, koji se do tada povezivao sa shizofrenijom, posuđen je od švicarskog psihijatra Eugena Bleulera. Kanner je smatrao da je autizam tip dječje psihoze uzrokovan ,neadekvatnim roditeljstvom” (za razliku od shizofrenije, koje su simptomi prisutni već od rođenja), uputivši na fenomen tzv. ,hladnih majki” koje se tretiraju kao nesvjesni uzročnici stanja svoje djece po osnovi uskraćivanja privrženosti i nedovoljne emocionalne posvećenosti, inače nužne za pravilan razvoj djece (Bujas-Petković, 1995). Ta je teorija danas potpuno napuštena, no u vrijeme odrastanja Temple Grandin bila je dominantno prisutna. Svakako valja napomenuti, neovisno o raspravi o samim uzrocima, da elementi vezani uz okolinu u kojoj osoba s poremećajem iz autističkog spektra odrasta i djeluje mogu imati blagotvoran, kao i destruktivan utjecaj na komunikacijske sposobnosti takvih osoba, a elementi obaju predznaka mogu se također razabrati iz studije slučaja koji razmatramo.

Posljednjih godina raspravi o poremećaju iz autističkog spektra doprinose i studije uloge zrcalnoga neuronskog sustava pri uspostavi socijalno-komunikacijskih definicija koje uključuju ne samo one čije su funkcije obuhvaćene teorijom uma, već i one koje se tiču prepoznavanja lica, imitiranja te u najširem smislu riječi empatije (Williams et al., 2006 prema Tager Flusberg, 2007: 311-315). Zrcalni neuroni prvi su put opisani kada su znanstvenici zapazili da su se neuroni smješteni u prefrontalnom motornom korteksu majmuna aktivirali njihovim izvršenjem određene zadane akcije, ali i kada bi istu akciju izvršila druga osoba, što je sugeriralo važnost zrcalnih neurona pri dekodiranju namjera drugih (Gallese, Fadiga, Fogassi, i Rizzolatti, 1996 prema Tager Flusberg, 2007: 311-315). Kako su komunikacijske poteškoće Temple vidljive upravo u nemogućnosti reproduciranja pojedinih slojeva komunikacijskih kodova te interpretiranja namjera drugih sudionika komunikacije, to upućuje i na dodatna pitanja umreženosti zrcalnoneuronskog sustava s izvršnim kognitivnim funkcijama, što je jedna od još uvijek otvorenih tema na koje će odgovor moći dati tek buduća istraživanja.

Navedene je uvide moguće nadopuniti i onima Raymonda Gibbsa koji oponašanje definira kao otjelovljenu kognitivnu aktivnost koju ljudske jedinke počinju razvijati neposredno nakon rođenja, a tiče se sposobnosti djeteta da uspostavi reprezentaciju 
vlastitih tjelesnih kretnji posredstvom „supramodalne” reprezentacije podražaja koje zaprima vizualnim putem, tj. konstruiranjem njihovog uzajamno podudarnog obrasca. Riječ je zapravo o stvaranju osobnoga senzomotoričkog obrasca procesom usuglašavanja s uzorima iz okoline, pri čemu je Gibbsovu perspektivu oponašanja kao aktivnosti svojstvene djeci, odnosno prilagođavanja materijalnom svijetu, moguće proširiti i na svijet odraslih (Biti i Marot Kiš, 2008). Zbog manjka u toj sferi, Temple teško može tumačiti geste drugih ljudi, baš kao što ima teškoća s razumijevanjem metafora ili sarkazma u govoru, indirektno povezanih s emocionalnim stanjima. Studije su pokazale da osobe s autizmom imaju poteškoće u interpretiranju emocija uopće (Boucher et al., 1998 prema Terzić i Drljan, 2011: 285-300), pa i u njihovom samomom imenovanju (Boucher et al., 2000 prema Terzić i Drljan, 2011: 285-300). Sve te komponente potrebne su za uspostavu socijalne kognicije koja, uz detekciju emocionalnih stanja, uključuje i obradu socijalnih signala te spoznaju o ljudima kao o društvenim bićima, odnosno sve kognitivne procese koji su aktivni u opažanju ponašanja i zaključivanju o mentalnim stanjima drugih ljudi (Škrobo, Šimleša i Pavliša, 2016: 6-13), a koji za osobe s poremećajem iz autističkog spektra predstavljaju golem, ponekad i nepremostiv izazov.

\section{Pogled na kognitivne specifičnosti Temple Grandin kroz prizmu filmskog djela redatelja Micka Jacksona}

Biografski film Temple Grandin (2010) redatelja Micka Jacksona pruža presjek mnogih izazova s kojima se od najranije dobi suočavaju osobe s poremećajem iz autističkog spektra. Temple vidi i tumači svijet na specifičan, okolini često nerazumljiv način. Osim teškoća koje nerijetko dovode do konfliktnih situacija, u filmu se akcentuiraju i izvanredne sposobnosti Temple Grandin kojima ona krči put prema svojoj životnoj vokaciji, što joj u konačnici omogućuje uspostaviti vlastitu nišu u društvenoj stvarnosti iz koje ne samo što uspijeva ostvariti zavidnu akademsku karijeru, već postaje i glasnogovornicom specifičnih potreba osoba s autizmom.

Temple je drugačija te iako njezina različitost opterećuje njezino odrastanje čuđenjem, podsmjesima, odbijanjem, pa i agresivnim ophođenjem okoline, njezina majka otklanja rano dobiveni liječnički savjet da svoju kćer prepusti brizi institucija, ustrajući u viđenju da njezina djevojčica u svojoj drugosti nije manje vrijedna te da, uz odgovarajuću podršku i poticaje, može svladati izazove redovitog školovanja i postati funkcionirajući član ljudske zajednice. Polaznu točku za problematizaciju izazova s kojima se suočava Temple Grandin redatelj Mick Jackson situira u njezine rane tinejdžerske godine, u ljeto koje Temple provodi na farmi svoje tetke. To je trenutak u njezinom životu koji prekretnički najavljuje izazove njezina odrastanja koje će donijeti njezin skori odlazak u internat, potom upis na fakultet i samo 
studiranje, a na koncu i njezino samostalno djelovanje u stečenoj struci. Svaka će od tih faza biti opterećena teškoćama, no isto će tako svaka nova teškoća u konačnici prerastati u pozitivan izazov s kojim će se Temple sučeljavati osnažena rastućom sviješću o vlastitu stanju, iskustvom svojih posrtanja, ali i stečenim vještinama premošćivanja prepreka. Upravo će ustrajnost u svladavanju izazova pretvoriti Temple u pobjednicu u njezinom cjeloživotnom pohodu na svoje pravo na različitost.

Iz odabrane polazne točke Jackson razvija temporalnu nit događanja u životu Temple Grandin u dva smjera - prema prošlosti i prema budućnosti. Iako je u strukturi filmskog uratka glavna ona nit koja se razvija u pravcu Templine budućnosti, za razumijevanje se njezina napretka pokazuje ključnom upravo mogućnost kontekstualizacije njezinih teškoća u vrijeme u kojem su se njezina stanja mogla činiti potpuno neuklopivima u realnost definiranu stereotipima „normalnosti”. Moglo bi se stoga reći da nit koja vodi prema prošlom predstavlja svojevrsnu filmsku anamnezu Templina poremaćaja, dok se ona, koja se kreće prema budućnosti, ponajviše tiče njezina ovladavanja vlastitom situacijom te je popraćena postupcima filmske dekonstrukcije socijalnih stereotipa spram kojih se Templina osebujnost čita kao progresivna i kao nadahnjujuća. Ovo potonje doista podcrtava sam credo ovoga filmskog djela, a to je da obilježja različitosti nipošto ne čine osobe iz autističkog spektra manje vrijednima, već da im - upravo suprotno - doznačuje posebnu i nezamjenjivu vrijednost koju ovo filmsko djelo uspješno uprizoruje.

U kontekstu motrenja poremećaja iz autističkog spektra kao komunikacijskog izazova, važno mjesto svakako pripada problematici svladavanja jezika. Znanje jezika usko je povezano s razvojem vještina u sferi teorije uma i tiče se koliko sposobnosti artikuliranja vlastite slike svijeta, toliko i sposobnosti razumijevanja jezičnih poruka pomoću kojih razvijamo predodžbe o slici svijeta naših sugovornika. Poremećaji iz autističkog spektra povezani su s teškoćama u svladavanju jezičnog koda, bilo da je riječ o razvojnom kašnjenju ili o potpunom izostanku komunikacije jezikom. Proces svladavanja jezika nadalje pripada interakcijskom kontekstu u kojem se značenje dane poruke ne razotkriva samo verbalnim znakovima, već i pomoću signalizacije pogledom, mimikom, gestikulacijom te govorom tijela, odnosno znakovljem koje je lišeno izravnih opipljivih i/ili vizualno predočivih korelata, što predstavlja dodatnu, nerijetko i nesavladivu teškoću osobama s autističkim poremećajem. Osim emocionalne inhibiranosti koja u pravilu rezultira izbjegavanjem samog kontakta, $\mathrm{u}$ velikom broju slučajeva te osobe značenja temelje u iskustvenim predodžbama podložnim vizualizaciji, povezujući slike izravno sa slikama u sintaksu koja se kudikamo razlikuje od one jezične, koju dopunjuju elementi poput aluzivnosti, metaforičnosti te mnogobrojnih vidova stilskih izvrtanja doslovnih značenja, nerijetko povezani s emocionalnim momentima te neizrečenim namjerama, kao i drugi znakovni sustavi na koje se jezik naslanja. 
U filmskom flashbacku na djetinjstvo tako susrećemo Temple Grandin kojoj majka pomaže pri svladavanju jezika služeći se vizualnim pomagalima, ne bi li joj preko slike mačke ili psa pomogla u kreiranju mentalnih reprezentacija i pri njihovom povezivanju s riječima kojima se ti pojmovi označavaju. Na farmi će joj njezina tetka na sličan način pokušati pomoći pri svladavanju apstraktnijih pojmova, onih vezanih uz emocionalna stanja, okružujući je fotografijama njezinoga vlastitog lica u stanju radosti, ljutnje, nezadovoljstva, bijesa.... Pokazuje se da će Temple uspjeti svladati pojmove za koje korelate nalazi u fizički ovjerljivoj iskustvenoj sferi, no da će joj oni apstraktni, posebice oni koji se vezuju uz ljudska stanja i emocije, ostati mahom nedohvatnima. Naime, mentalne reprezentacije takvih stanja nisu povezane samo s podražajima i s bazičnim kognitivnim vještinama koje funkcioniraju kroz paralelne procesne mehanizme te omogućuju slikovnu reprezentaciju, već i s uopćenim, društveno prihvaćenim (ili prihvatljivim) interpretacijama (Lucke, Kostova i Roth, 2014: 169-190) koja takva stanja situiraju u situacijske kontekste. Takve interpretacije Temple Grandin ne prepoznaje koliko zbog senzornih, toliko i zbog kognitivno-procesnih specifičnosti koje determiniraju funkcioniranje njezine svijesti. Njezin „osjećaj postojanja” (Damasio, 2005) određen je njezinom hiperosjetljivošću na vanjske podražaje - čega je zoran primjer scena u filmu u kojoj je osjet vrućine, koji će zapahnuti Temple prilikom izlaska iz aviona, vizualiziran kao vatreni toranj - i takvo je perceptivno stanje čvrsto privezuje uz iskustva vlastita tijela, sprečavajući zauzimanje promatračkog odmaka primarno spram sebe same (Damasio bi to nazvao nepotpunom uspostavljenošću njezina autobiografskog ,ja”), ometajući proces nužne desubjektivacije vlastitih iskustava nužan za procjenu psihofizičkih stanja drugih ljudi.

Iz razgovora Temple i njezinoga srednjoškolskog učitelja, profesora Carlocka, razotkrit će se neobična nuspojava takvoga mentalnog ustroja, a to je Templina nevjerojatna sposobnost pamćenja pojedinačnih pojava - primjerice, svih ikad viđenih konja ili svih ikad viđenih cipela, dozvanih kumulacijom i brzom izmjenom filmskih kadrova koji korespondiraju s viđenim, bilo iz Templina izravnog iskustva ili iz iskustava posredovanih televizijskim medijem. Stoga je moguće razabrati da pojam 'konj' ili ‘cipela' u Templinu svijest doziva praktički neograničen skup pojedinačnih predmeta, a ne njihovu apstraktnu sumu podvedivu pod shemu opće imenice. Filmska kamera zorno predočuje činjenicu da Temple ne ekonomizira sa svojim iskustvom pa mu stoga ni ne pristupa sintetički, da se sukladno tome u procesu zaključivanja ne služi dedukcijom kao metodom filtriranja informacija koje pohranjuje u memoriju. Ona, sasvim suprotno zakonima dedukcije, kumulira slike u beskonačne arhive, a zaključke izvodi slijedeći logiku indukcije, odnosno povezivanjem pojedinačnog s pojedinačnim i viđenog s iskustveno provjerljivim. Učinak takvoga kognitivnog procesuiranja s jedne je strane manjak snalaženja u područji- 
ma u kojima jezik funkcionira kao glavni alat spoznaje, no s druge strane, nevjerojatna lakoća priziva i međusobnog kombiniranja iskustvenih nizova te daljnja vizualizacija ishoda tih procesa. Muku joj stoga predstavlja učenje francuskog jezi$\mathrm{ka}$, no probleme iz fizike rješava s lakoćom, štoviše, nadvisujući druge učenike. Ona će francuski „il est” (,on jest”) prizvati u pamćenje poistovjećujući francusku zamjenicu i glagol s podudarnim zvukovima u engleskoj kombinaciji riječi „eels ate” (,jegulje su jele”), a u svojoj će bilježnici tu vezu popratiti crtežom dviju jegulja koje objeduju za stolom. Razvidno je da ona jezik čuje kao nizove zvukova koje prevodi u slike logikom najbližeg, rekli bismo, i najdoslovnijeg iskustva koje je u stanju vizualizirati, dok u isto vrijeme zakazuje u području deduktivne primjene jezika. U pozadini njezine nesnalažljivosti s jezikom profilira se tako njezina izuzetna snalažljivost kada se zatekne na terenu praktičnih pitanja, napose u sferi prirodnih znanosti. Budući da s računalom lakoćom polučuje podatke iz neiscrpnih memorijskih arhiva kojima raspolaže, s tim podacima kombinira povezane slike u nove slike. Precizno predviđajući za druge nepredvidive ishode, ona postaje tvorcem mnogih inovativnih rješenja kojima rješava probleme iz opipljive, fizikalne sfere. Moglo bi se reći da ona svoje manjkove na planu sinteze i dedukcije kompenzira izuzetnim memorijskim i kombinatoričkim sposobnostima, što će se pokazati kao njezina prednost koja će joj omogućiti da se afirmira kao stručnjakinja u području znanosti o životinjama.

Posebnu pažnju Jackson posvećuje poteškoćama u primanju i obradi senzornih podražaja iz okoline koje se ponekad manifestiraju kao senzorna hipoosjetljivost, a ponekad kao hiperosjetljivost. Dok se čini da hipoosjetljivost Temple Grandin, zamjetna u ranijem djetinjstvu - razvidna, primjerice, u sceni njezine zagledanosti u kristalni luster i neosvrtanje na majčin glas dok je majka pokušava učiti da govori - $\mathrm{s}$ odrastanjem jenjava, njezina hiperosjetljivost $\mathrm{s}$ rastom zaprima sve raznolikije $\mathrm{i}$ dramatičnije vidove. Temple, primjerice, drugačije od drugih ljudi procesuira zvukove, što razabiremo iz njezine reakcije na šum ventilatora u spavaonici u koju je smješta njezina teta, ali i iz njezinih reakcija na žamor i smijanje ljudi na proslavama i druženjima. Hiperosjetljiva je i na taktilnom planu: ne voli se grliti čak ni s bliskim osobama, a tjelesni je kontakt - bilo to i srdačno tapšanje po ramenu duboko uznemirava. Ne osjećajući se dobro među ljudima čije reakcije često doživljava kao opstrukciju svojega privatnog prostora, Temple na farmi svoje tete otkriva da bolje razumije životinje te razvija osebujan odnos bliskosti s tim bićima koja, pomalo poput nje same, žive sapeta pravilima koja im nameću ljudi i trpe jaram ljudskih postupanja. Dok prati proceduru cijepljenja krava, ona otkriva začudni umirujući učinak koji na te životinje ima stroj koji ih stisne s bokova, na koji se u filmu referira nazivom „the squeeze machine”. Na čuđenje svoje tetke, ona taj stroj isprobava na sebi te otkriva da i na nju samu on djeluje umirujuće. Ona stoga odlu- 
čuje samoj sebi izraditi sličnu napravu kako bi se mogla, u trenucima stresa, podvrgavati impersonalnom zagrljaju koji joj pruža stisak tvrdih stranica njezine ,mašine za grljenje". Za svoje pravo na služenje napravom koja na nju ima stabilizirajući učinak, Temple će se s mukom izboriti na fakultetu gdje će se njezino podvrgavanje ritualu umjetnoga grljenja tumačiti kao nastrano ponašanje i biti stigmatizirano kao neka vrsta nastrane seksualne gratifikacije. Boreći se za svoje pravo da se povlačenjem u stisak tvrdih ploča svoje naprave othrva stresovima života u studentskoj zajednici, Temple će posegnuti za obrascem čiju legitimnost uprava fakulteta neće moći osporiti - onim istraživačkim. Njezin istraživački rad na temu djelovanja „,mašine za stiskanje", utemeljen u metodološki besprijekorno provedenom eksperimentu, poduprtim reprezentativnim uzorkom ispitanika koji su se svojevoljno podvrgnuli ispitivanju i kontrolnom grupom, priskrbit će joj na koncu ne samo najviše ocjene nego i pravo da se svojim strojem nastavi služiti. Bit će to ujedno i njezina prva velika pobjeda koja će joj ne samo osigurati pravo na prakticiranje različitosti, već će joj poslužiti i kao model za prevladavanje budućih predrasuda s kojima će se i nakon stjecanja diplome nastaviti suočavati. Otkrivši da se stereotipima i predrasudama može suprotstaviti, ona otkriva i da se učinkovito sredstvo suprotstavljanja obično krije unutar samih obrazaca koji oblikuju ponašanje većine, tj. da mora uzmoći prepoznati i upotrijebiti onaj obrazac koji može upotrijebiti u vlastitu korist. Upravo će tako Temple postupiti iznova kada će se naći na nišanu diskriminatorne politike uprave farme Scottsdale Arizona koja će je htjeti omesti u njezinom istraživanju, vezanom uz ponašanje stoke. Nakon neuspjela pokušaja da na farmu uđe zaodjenuta u uprljanu mušku odjeću kakvu inače nose djelatnici farme, ona će se dosjetiti mogućnosti da preko svojeg izdavača nabavi novinarsku iskaznicu koja nositelju osigurava pravo pristupa farmi. Time će ujedno postati i prvom ženskom, štoviše, autističkom osobom s legitimitetom radnog boravljenja unutar stereotipiziranoga muškog farmerskog ustroja.

Iako je iz brojnih situacija prikazanih u filmu više nego razvidno da slučaj Temple Grandin korespondira sa simptomatologijom deficita u sferi teorije uma tipičnih za osobe s autizmom (Frith, 1989; Baron-Cohen, 1992: 1141-1155), te da ona u svojem narativnom diskursu nije u stanju oprimjeriti informacije pažnji, znanju i perspektivi svojih slušatelja, netom opisane situacije pokazuju da je i taj deficit moguće u određenoj mjeri nadići, dakako uz pretpostavku odgovarajuće motivacije samog subjekta, kao i cjeloživotne potpore kakvu je Temple imala sreće dobiti od svoje majke, tetke, profesora Carlocka, pa i od svoje slijepe prijateljice s kojom je tijekom studiranja dijelila sobu. Nadilaženje tog deficita neće se odraziti u konverzacijskoj sferi u kojoj će Temple zauvijek ostati svojevrsnim strance koji sugovornike obasipa detaljima njima stranih tema, neprimjereno glasnim govorom te čudnovatim ponavljanjem pojedinih ritualnih rečenica. Ono se može odraziti na rješavanje kon- 
kretnih problema koji proizlaze iz šire socijalne interakcije. Temple, naime, ne može zauzeti perspektivu „druge strane” ni razumijevati razloge ponašanja koji izlaze iz sfere njezinog iskustva, no ona može pristupati temama poput zabrane pristupa farmi uvrštavanjem konkretnih problema u vlastiti iskustveni kalkulus, tretirajući pritom svaki pojedinačni problem kao nepoznanicu koju može ukloniti iz socijalne jednadžbe putem operacija analognih matematičkom rješavanju kompleksnih zadataka. Pritom se iznova njezin deficit pokazuje kao svojevrsna prednost: da je nekim slučajem Temple u stanju razumjeti fenomen diskriminacije, vjerojatnije je da bi se pred njim povukla uvažavajući ga kao svojevrsnu „višu silu“" kojoj se nitko, pa ni ona, ne može suprotstaviti. Ona se, međutim, ne zaokuplja uzrocima fenomena koji se pred nju preprečuju, već samo posljedicama s kojima je suočena, odnosno s konkretnom stavkom koja za nju predstavlja svojevrsni x zamjenjiv odgovarajućom korelativnom vrijednošću. Ta korelativna vrijednost, kada je $\mathrm{x}=$ zabrana pristupa farmi, postaje - nakon niza pokušaja i pogrešaka - novinarska iskaznica. Do rješenja kojemu teži, Temple ne stiže pokušajima razumijevanja pa ni razuvjeravanja druge strane, kako bi po svoj prilici postupila osoba neopterećena deficitima u sferi teorije uma. Ona soluciju ostvaruje obradom iskustvenih podataka koje tretira kao impersonalne vrijednosti koje podliježu kombiniranju, sve dok se ne dosegne zacrtani cilj, a to je rješavanje samog problema. Iako je njezin postupak zaključivanja specifičan i drukčiji, sličniji operacionalizaciji umjetne inteligencije nego one koju običavamo nazivati prirodnom, on se neupitno dotiče metakognitivne razine rješavanja problema. Ona svoja iskustva označujem, podatke pretvara u metapodatke, što joj omogućuje i da ih sučeljava, selektira te da za njih nalazi i odgovarajuće primjene.

Metakognicija se definira kao razmišljanje o razmišljanju i podrazumijeva procese nadgledanja i prilagođavanja misli i strategija koje vode prema svladavanju novih vještina (Triands, 1995 prema Mor, Morris i Joh 2013: 453-475). Proces metakognicije u pravilu donosi svjesnost o sebi samom te senzibiliziranost spram drugih, omogućujući prilagodbu okolini i situacijama u kojima se zatičemo (Mendenhall i Oddu, 1985 prema Mor et al., 2013: 453-475), kao i razvoj strategija usvajanja i prilagođavanja novih znanja i vještina. U slučaju Temple Grandin pokazuje se, međutim, da se put od neposrednog opažaja do metakognitivne razine, koja joj omogućuje da opažaj stavi u funkciju strategije, može razvijati i drugim putevima, koji mogu zaobići brojne aspekte prilagođavanja socijalnoj sferi. Iz toga slijedi da se metakognicija može ticati i drugačije vrste samosvijesti, one koja vlastite deficite ne problematizira već ih, do mjere u kojoj to može i u sferama u kojima to može, ustanovljuje i tretira kao zadane vrijednosti u srazu sa skupom nepoznanica i varijabli koje označavaju ponašanje većine, za Temple rješivih u onoj mjeri u kojoj se uzorci ponašanja ponavljaju i time otvaraju operacijama matematičkog zaključivanja. 
Optimistična je to poruka za osobe s deficitom iz autističkog spektra koja svjedoči o tome da je razvoj kognitivnih sposobnosti moguć pa i do viših razina, povrh i pored zadana deficita, iako ishodi tog razvoja u velikoj mjeri i nadalje odstupaju od većinske percepcije ,normalnog” ponašanja. O izgrađenoj samosvijesti Temple Grandin svjedoči u konačnici i njezino izlaganje o vlastitim iskustvima na skupu stručnjaka koji se bave autizmom. Upravo se rakurs poput njezinog pokazuje ključnim za problematizaciju kognitivnih limita ,normalne” većine koju njezina ,normalnost" ometa primjerice u shvaćanju važne samosmirujuće uloge, koju opsesivno kružno kretanje ima za autističke osobe. Stoga će Temple biti ta koja će prenijeti stručnjacima da se tu ne radi o bihevioralnoj manifestaciji koju je potrebno obuzdavati i sprečavati, nego upravo obrnuto. Drugost naime nije ni poželjno ni moguće utjeravati u modele ,,istosti”, no moguće je i poželjno je uvažavati je i time joj omogućiti razvitak i unaređenje.

\section{Zaključak}

Predočujući (primarno vizualizirajući, ali i ozvučujući) mentalne procese protagonistkinje filma te sučeljavajući ishode tih procesa sa socijalnim kontekstima unutar kojih se odvija njezina egzistencija, biografski film Temple Grandin pruža uvid u misaono i emotivno funkcioniranje osoba s poremećajem iz autističkog spektra. Opredjeljujući se za kombinirani vid temporalnosti koji s jedne strane nudi kronologiju Templioga životnog puta i mentalnog razvoja, a s druge strane tom putu sučeljava retrospektivu sličica iz njezinoga ranijeg djetinjstva, redatelj Mick Jackson odlučuje se za grupiranje filmskih postupaka oko onih fokalnih točaka koje razotkrivaju inače teško uhvatljive dinamičke momente, koji izranjaju iz presjeka mentalne i fizičke stvarnosti, generirajući konflikte i izazove kao okidače kognitivnim procesima čiji ishodi migriraju iz subjektivne domene u onu objektivnu, $\mathrm{i}$ povratno. Redateljeva tehnika slaganja prizora konkretnoga unutarnjeg i vanjskog života konkretne ljudske jedinke dijagnosticirane poremećajem iz autističkog spektra pomalo je nalik metodi sučeljavanja zrcala u kojima se međusobno ogledaju perceptivne i kognitivne osebujnosti same Temple Grandin, ali i socijalni stereotipi koji osebujnim bićima poput nje otežavaju pristup u socijalnu sferu. Temple je mahom osuđena živjeti na rubu, koliko zbog vlastitog odmaka od stereotipa u koje se ne uklapa, toliko i zbog okoline čiji doseg razumijevanja drugosti zastaje pred socijalnim normama koje determiniraju način života dane zajednice, zaprimajući i dramatične oblike kada dovede do izravnih diskriminatorskih praksi koje teže izopćenju svake različitosti. Pred brojnim zaprekama, pred kojima se Temple zatiče, bez sumnje bi bilo lakše posustati nego ustrajati, što je solucija koju će njezina majka, a kasnije i sama Temple, slijedeći svoje pronađene životne interese, doživjeti kao 
O misaonim procesima osoba s poremećajem iz autističkog spektra...

neprihvatljivu. Temple će se - uz dragocjenu potporu malobrojnih ali važnih bliskih osoba, no ujedno i rukovođena svojom željom da uzgoj životinja oplemeni inovativnim humanim rješenjima - nastaviti kretati prema svojem cilju, gradeći svoje vještine svladavanja prepreka i svoju sposobnost da se odupre negativnim strujanjima. Upravo će se neposustajanje pokazati ključnim i za njezin kognitivni razvoj koji, suprotno svim očekivanjima, doseže razinu svijesti o vlastitu poremećaju, kao i razinu ne samo intelektualnih nego i nužnih socijalnih kompetencija potrebnih za ostvarenje akademske karijere. To njezino neprestano kretanje, praćeno čestim posrtanjem, no uvijek iznova i novim otkrićima, oživotvoruje se pokretnim slikama filmskog medija na način koji uspostavlja upravo onu perspektivu koja knjišku dimenziju njezine dijagnoze postaje kadrom privesti stvarnom razumijevanju različitosti kao vrijednosti.

U tom svjetlu, svakako se čini vrijednom daljnjeg propitivanja u teoriji filma prisutna teza da iskustvo gledanja filma (film-viewing experience) može stimulirati nizove socijalnim praksama uspavanih kognitivnih funkcija, odnosno da udružena snaga mimesisa (kao vizualne reprezentacije) i kinesisa (kao kretanja kroz vrijeme) doista može pokrenuti, kao što sugerira teoretičar filma Gerald Mast, virtualno iskustvo stvarnoga življenja kadro dozvati, ali i prevesti u razumijevanje, iskustva drugosti (Mast, 1977). Problematika je to koja poziva koliko na istraživanje suodnosa medijski konstruirane reprezentacije i stvarnih iskustvenih korelata unutar kognitivnog procesa, toliko i na dublje propitivanje samog epistemološkog statusa filma kao prijenosnika znanja, odnosno kredibilnosti i uvjerljivosti svakoga pojedinačnog faktora epistemološkog kruga te objektivnih i subjektivnih preduvjeta komunikacijske suradnje između tvorca filmskog djela i gledatelja. Osnove za propitivanje potonjeg moguće je pronaći i u teorijama čitanja, odnosno recepcije, polazeći od temelja koje su postavili teoretičari poput Romana Ingardena (1973) i Wolganga Isera (1978), uputivši na kognitivnu relevantnost temporalne organizacije čitateljskog predloška, pritom sagledavajući primatelja ne samo kao adresata, već i kao sukreatora značenja. Polazišta su to koja otvaraju prostor daljnjim izučavanjima relacija između iskustva čitanja linearnog teksta, koji temporalnost priče podvrgava reorganizaciji omogućujući vizualnost priziva, te iskustva čitanja filma koje integrira vizualne i akustičke momente, čime se otvaraju i brojna pitanja vezana uz načine konstruiranja kognitivnih shema, načine njihovoga međusobnog povezivanja i arhiviranja, pitanja pasivnosti i aktivnosti u činu rekonstruiranja filmom posredovane realnosti. U konačnici se tiče i samih mehanizama zaprimanja i kognitivnog procesuiranja tekstualno, odnosno vizualno posredovanih podražaja, njihovog prevođenja u slike stvarnosti te njihove pretvorbe u znanje, značenje i razumijevanje.

$\mathrm{Na}$ koncu, valja reći i to da nas sama činjenica, da pitanja recepcije filmskog značenja predstavljaju otvoren istraživački izazov, ne treba omesti pri akceptiranju film- 
skih predložaka kao arhiva ljudskog iskustva i znanja, posebice kada je riječ, kao u slučaju netom analizirana predloška, o znalačkim obradama specifičnih stanja ljudskog uma koja uvelike izmiču verbalnom opisu, a nerijetko još i više stvarnom razumijevanju drugih i drugačijih realiteta od onog ili onih koje prihvaćamo kao socijalizirane jedinke, koje svoju percepciju svijeta prilagođavaju općeprihvaćenim vrijednostima i idejama socijalnog reda. Valja imati na umu da socijalne definicije vrijednosti i ideje tzv. reda podliježu stalnom redefiniranju, i da tom redefiniranju ponajviše pomažu upravo umjetničke prakse koje propituje pojave koje se zatiču na graničnim pozicijama socijalnih ustroja, prokazujući diskriminatorne oblike djelovanja te afirmirajući opće pravo na život i stvaranje svih ljudskih jedinki, bez obzira na moguće različitosti povezane s njihovim individualnim fizičkim ili kognitivnim predispozicijama. Stoga smatramo izuzetno važnim da djela poput filma Temple Grandin pronađu svoj put i do laboratorija znanstvene misli koja, poput svake druge misli, evoluira nasuprot predrasudama o koje se i sama na svojem razvojnom putu zapliće i iz kojih se neprestanim naporima obuhvaćanja šire slike jednako tako raspliće. I znanstveni uvidi svoju validnost, naime, potvrđuju u sferi stvarnih životnih iskustava koja mediji poput književnosti ili filma znalački okupljaju, čineći ih uvijek iznova dostupnima.

\section{LITERATURA}

Američka psihijatrijska udruga (2014) DSM-5 Dijagnostički i statistički priručnik za duševne poremećaje.

Anderson, P. (2002) "Assessment and development of executive function (EF) during childhood", Neuropsychology, 8, 71-82. doi: 10.1076/chin.8.2.71.8724.

Biti, M. i D. Marot Kiš (2008) Poetika uma. Osvajanje, propitivanje i spašavanje značenja. Zagreb: Hrvatska sveučilišna naklada. Izdavački centar Rijeka.

Baron-Cohen, S. (1992) "Out of sight or out of mind: Another look at deception in autism”, Journal of Child Psychology and Psychiatry, 33, 1141-1155. doi: 10.1111/j.1469-7610.1992.tb00934.x.

Bujas - Petković, Z. (1995) Autistički poremećaj. Zagreb: Školska knjiga.

Damasio, A. (2005) Osjećaj zbivanja. Tijelo, emocije i postanak svijesti. Zagreb: Algoritam.

Frith, U. (1989) Autism: Explaining the enigma. Oxford: Blackwell.

Ingarden, R. (1973) The cognition of the literary work of art. Evanston, Illionois: Northwestern University Press.

Iser, W. (1978) The act of reading: A theory of aesthetic response. Baltimore: John Hopkins University. 
O misaonim procesima osoba s poremećajem iz autističkog spektra...

Kanner, L. (1943) "Autistic Disturbances of Affective Contact", Nervous Child: Journal of Psychopathology, Psychotherapy, Mental Hygiene, and Guidance of the Child, 2, 217-250. doi: 10776/7895.

Lucke, G., Kostova, T., i K. Roth (2014) "Multiculturalism from a cognitive perspective: Patterns and implications", Journal of international business studies, 45, 169-190.

Mast, G. (1977) Film/cinema/movie: A theory of experience. New York: Harper and Row.

Mor S., Morris M. i J. Joh (2013) "Identifying and training adaptive cross-cultural management skills: The cruical role of cultural metacognition", Academy of management learning\&education, 12 (3), 453-475. doi: 10.5465/amle.2012.0202.

Tager-Flusberg, H. (2007) "Evaluating the Theory-of-Mind Hypothesis of Autism", Current directions of psychological science, 16, 311-315. doi: 10.1111/ j.1467-8721.2007.00527.x.

Šimleša, S. (2011) "Izvršne funkcije i teorija uma kod osoba s poremećajem iz autističkog spektra", Psihologijske teme, 20 (1), 91-114.

Škrobo, M., Šimleša, S. i Ivšac Pavliša, J. (2016) Obilježja socijalne kognicije kod osoba s poremećajem iz spektra autizma, posebnim jezičnim teškoćama i intelektualnim teškoćama. Logopedija, 6 (1), 6-13. https://doi.org/10.31299/ log.6.1.2.

Terzić, I. i B. Drljan (2011) "Deficiti pojedinih aspekta pragmatike osoba s poremećajima autističkog spektra", Specijalna edukacija i rehabilitacija, 10 (2), 285-300. doi: 1452-7367.

Wellman, H. M., Cross, D. i J. Watson (2001) "Meta-analysis of theory-of-mind development: The truth about false belief", Child Development, 72, 655-684. doi: 10.1111/1467-8624.00304. 


\title{
On Thought Processes of Persons Suffering from ASD from the Perspective of Their Representation in Film: The Case of Temple Grandin
}

\section{Marina Biti}

\author{
Eva Brlek
}

\section{SUMMARY}

Objective causes of Autistic Spectrum Disorder as well as difficulties in communication are being scrutinized from a neurocognitive perspective. The platform for the discussion goes on to being expanded further in a case study observed through the prism of Mick Jackson's film Temple Grandin. The analysis points to properties of the film medium, and of creative practices in general, that enable deeper insight into cases of Autistic Spectrum Disorder, helping to eliminate prejudicial attitudes that persons suffering from ASD often encounter in the social environment, contributing to better forms of their treatment and enabling enhancements in the area of communicative practices, thus increasing their chances for fuller integration into the social sphere.

Keywords: Autistic Spectrum Disorder, theory of mind, otherness, mimesis, kinesis 